\title{
Spontaneous Generation of Neurospheres from Mouse Embryonic Stem Cells
}

\author{
Roberto Di Maio', Kommu Naga Mohan², \\ Brianna Heath ${ }^{3}$ and Leonardo D' Aiuto ${ }^{4}$ \\ ${ }^{1}$ Department of Neurology, University of Pittsburgh, E Ri.Med Foundation, Palermo \\ ${ }^{2}$ Department of Molecular and Human Genetics, Baylor College of Medicine \\ ${ }^{3}$ Department of Human Genetics, Graduate School of Public Health, \\ University of Pittsburgh, \\ 4 Department of Psychiatry, University of Pittsburgh School of Medicine, \\ Western Psychiatric Institute and Clinic \\ ${ }^{1}$ Italy \\ 2,3,4 United States
}

\section{Introduction}

Neural stem cells (NSCs) are self-renewing pluripotent cells that can produce different parts of the nervous system. NSCs were initially identified in the subventricular zone of the mouse brain (Temple, 1989) and subsequently in various regions of adult brains from human and mouse (Taupin \& Gage, 2002). NSCs can be derived in vitro from embryonic stem (ES) cells and induced pluripotent stem (iPS) cells by employing specific culture conditions. NSCs and their progeny can be expanded for several passages as tridimensional floating aggregates named neurospheres or as monolayer cultures. This in turn allows derivation of neurons of different parts of the nervous system (Gaspard \& Vanderhaeghen, 2011). NSCs derived from ES/iPS cells of various genetic backgrounds represent invaluable tools for the investigation of neurogenesis, development of neurologic diseases models, and screening of new drugs to treat neurological diseases.

Derived from ES cells, NSCs and their progeny, neural progenitors, are routinely studied in vitro by a method called neurosphere culture system (Reynolds \& Weiss, 1992). Neurospheres can measure 100-300 mm. The zonal distribution of different cell types that compose human and murine neurospheres resembles an outside-in brain structure with nestin-positive progenitor cells in the periphery and GFAP+ and $\beta$-tubulin III-positive cells in the centre (Moors et al., 2009; Campos et al., 2004).

Currently, there are two methods that allow derivation of neurospheres from mouse ES cells. Both of these methods utilize fibroblast growth factor 2 (FGF-2), epidermal growth factor (EGF), retinoic acid, and other supplements such as B27 and N2. FGF-2 is a critical component in neural differentiation protocols as it promotes proliferation of neuroprogenitor cells (Yoshimura et al., 2001). For selecting and expanding neural progenitor cells, culture media are supplemented with B-27 (containing retinoic acid) and N2 (which has a subset of component of B-27 that include insulin and transferrin). 
In one method of derivation, ES cells are cultured in a specific medium supplemented with EGF, FGF-2 and N2. After 4-5 days, $50-80 \%$ of the cells undergo neural lineage specification. On day 7 , these cells are dissociated and plated in suspension in uncoated plates in a differentiation medium supplemented with N2, B27, mouse EGF and human FGF-2. After a few days of culturing, neurospheres can be obtained (Conti et al., 2005).

Alternatively, in a second method, mouse ES cells are co-cultured for approximately one week with the PA6 stromal cell line to achieve efficient neuronal differentiation because of the stromal cell-derived inducing activity (SDIA) (Kawasaki et al., 2000). After 8 days of SDIA treatment, mouse ES cells are separated from PA6 stromal cells and cultured in suspension in serum-free medium supplemented with FGF-2. Under these conditions neurospheres appear within 4 days (Morizane et al., 2006).

Exemplifying stages of the neurosphere generation process are shown in figure 1 .

The ability of mouse ES cells to spontaneously generate neurospheres and mature neurons in short time and in few steps, represents the strength for a powerful and reliable in vitro model to apply research strategies oriented to study the physiopathology of the biochemical and epigenetic mechanisms leading to the neurogenesis.

We recently observed that mouse ES cells when grown in simple culture conditions spontaneously form neurospheres. In this chapter, we describe a simple method for derivation of neurospheres from mouse ES cells without using FGF-2 and EGF and without co-culturing ES cells with stromal cells.
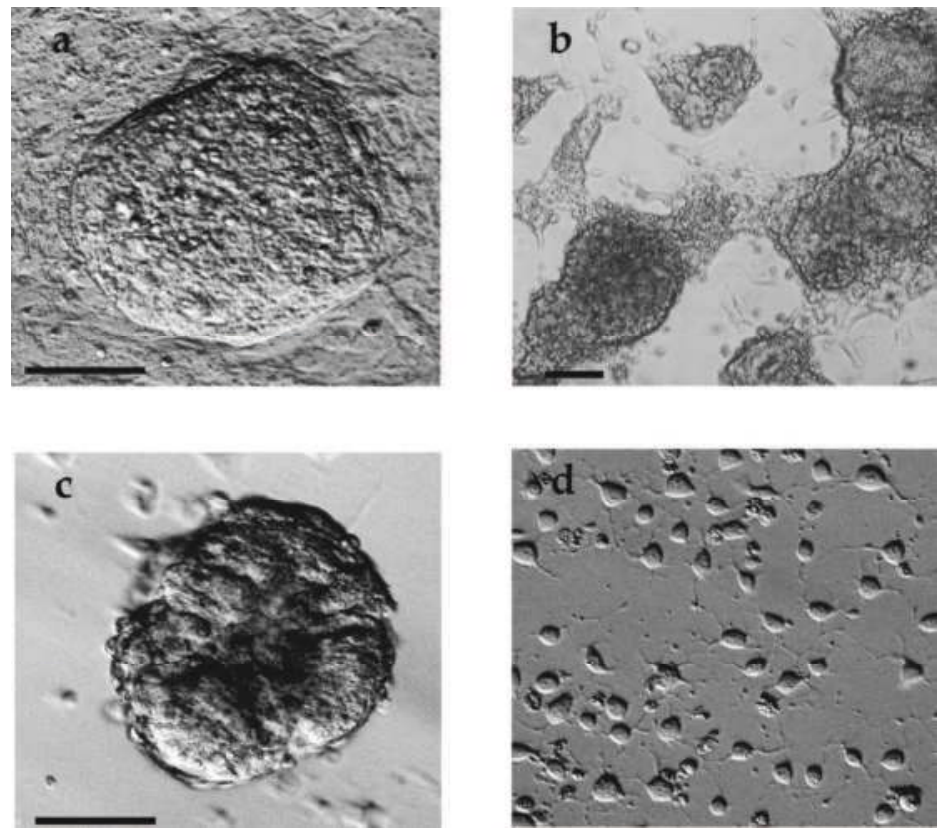

Fig. 1. Generation of neurospheres from mES cells. a) Microphotograph of a mES colony; b) typical clusters of cells generated after culturing R1 mES for three passages in a DMEM/FBS medium; c) bright field of a neurosphere; $d$ ) progenitors migrating from neurospheres. [Images taken by authors.] Scale bar $1 \mathrm{~s} 100 \mathrm{~mm}$. 


\section{Reagents and equipment}

The reagents and equipment needed for the methods described in this chapter can be found listed in the tables below.

\begin{tabular}{|c|c|c|}
\hline Equipment & Company & Catalog \# \\
\hline $0.22-\mu \mathrm{m} 500 \mathrm{ml}$ bottle top filter & Corning & 430513 \\
\hline $0.22-\mu \mathrm{m} 250 \mathrm{ml}$ filter system & Corning & 430767 \\
\hline $10 \mathrm{~cm}$ cell culture dish & Corning & 439167 \\
\hline $\begin{array}{l}\text { 24-well plates (Transwell-Clear } \\
\text { permeable support } 0.4 \mu \mathrm{m}\end{array}$ & Fischer & $07-200-154$ \\
\hline 6-well ultra low attachment plate & Costar & 3471 \\
\hline 15-ml polypropylene conical tubes & BD Falcon & 352096 \\
\hline 50-ml polypropylene conical tubes & BD Falcon & 352070 \\
\hline Transfer pipettes & Samco & $262-1 S$ \\
\hline $0.22-\mu \mathrm{m}$ bottle top filters & $\mathrm{TPP}$ & 99505 \\
\hline $0.45-\mu \mathrm{m}$ bottle top filters & Nalgene & $165-0045$ \\
\hline $12 \mathrm{~mm}$ circular cover slips & Fisher & $01-472 \mathrm{~A}$ \\
\hline Hemocytometer & Hycor Kova & 87144 \\
\hline \multicolumn{3}{|l|}{ 1000-ml media bottles } \\
\hline Kimwipes & Kimberly-Clarks & 34155 \\
\hline $\begin{array}{l}\text { Humidified tissue culture incubator } \\
\left(37^{\circ} \mathrm{C}, 5 \% \mathrm{CO}_{2}\right)\end{array}$ & - & - \\
\hline Centrifuge & - & - \\
\hline Water bath $\left(37^{\circ} \mathrm{C}\right)$ & - & - \\
\hline Scanning confocal microscope & Olympus & FluoView 100 \\
\hline $\begin{array}{l}\text { DM IRM inverted microscope } \\
\text { (fitted with Leica HS N Plan BD 50X } \\
\text { oil immersion objective) }\end{array}$ & Leica & - \\
\hline $\begin{array}{l}75 \mathrm{~W} \text { xenon lamp-based } \\
\text { monochromator }\end{array}$ & Ushio, Japan & - \\
\hline CCD camera & $\begin{array}{l}\text { Orca (Hamamatsu, Shizouka, } \\
\text { Japan) }\end{array}$ & - \\
\hline $535 \pm 40 \mathrm{~nm}$ bandpass filter & Omega Optical & - \\
\hline $500 \mathrm{~nm}$ longpass dichromatic mirror & - & - \\
\hline Simple PCI & Compix, Inc (Cranberry, PA) & - \\
\hline
\end{tabular}

Table 1. Equipment needed for the methods described in this chapter. 


\begin{tabular}{|c|c|c|}
\hline Reagent & Company & Catalog \# \\
\hline R1 ES cells & $\begin{array}{l}\text { Mutant Mouse Regional } \\
\text { Resource Centers }\end{array}$ & 011979-MU \\
\hline Non-essential amino acid solution (100X) & Millipore & TMS-001 \\
\hline Nucleosides (100X) & Millipore & ES-008-E \\
\hline L-glutamine (100X) & Millipore & TMS-002-C \\
\hline Penicillin/Streptomycin (100X) & Millipore & TMS-001 \\
\hline 2-Mercaptoethanol (100X) & Millipore & ES-007-E \\
\hline Sodium pyruvate $(100 \mathrm{mM})$ & Cellgro & $25-00-\mathrm{CI}$ \\
\hline Trypsin-EDTA (100X) & Gibco & 15400 \\
\hline $\begin{array}{l}\text { Dulbecco's phosphate buffered saline (10X) } \\
\text { (PBS) }\end{array}$ & Sigma & P-3813 \\
\hline Gelatin from porcine skin (Type A) & Sigma & G1890 \\
\hline $\begin{array}{l}\text { Dulbecco's modified Eagle's medium } \\
\text { (DMEM) }\end{array}$ & Millipore & SLM-220-B \\
\hline Fetal bovine serum (ES cell grade) (FBS) & Gibco & 16141-079 \\
\hline Knockout Serum Replacement (KSR) & Invitrogen & 10828028 \\
\hline Neurobasal medium & Invitrogen & 21103-049 \\
\hline Phosphate buffered saline (PBS) & Gibco & 14040141 \\
\hline Poly-D-lysine (PDL) hydrobromide & Sigma & P6407 \\
\hline Leukemia inhibitory factor (LIF) $\left(10^{7}\right)$ & Millipore & ESG1107 \\
\hline B27 & Invitrogen & $17504-044$ \\
\hline N2 supplement & Invitrogen & $17502-048$ \\
\hline FGF-basic Recombinant Mouse & Invitrogen & PMG0035 \\
\hline Laminin & Sigma & L2020 \\
\hline BisBenzimide H 33342 trihydrochloride & Sigma & B-2261 \\
\hline Mounting solution & Gelvatol & - \\
\hline $\begin{array}{l}\text { Paraformaldehyde (16\% in premixed PBS } \\
\text { buffer at } \mathrm{pH} \text { [below]) }\end{array}$ & $\begin{array}{l}\text { Electron Microscopy } \\
\text { Sciences }\end{array}$ & $15710-6$ \\
\hline PBS buffer at pH7 (1X) & Roche & 11666789001 \\
\hline 10\% Normal Donkey Serum (NDS) & Jackson ImmunoResearch & 711-165-152 \\
\hline $0.01 \%$ TritonX-100 & Fluka & BP151-100 \\
\hline Tubulin III & R\&D Systems & MAB1195 \\
\hline Rabbit Anti-NMDAR1 & Abcam & Ab68144 \\
\hline Bovine albumin & Sigma & A-6003 \\
\hline Fura-2, AM cell-permeant & Invitrogen & F-1221 \\
\hline Cy3 AffiniPure Donkey Anti-Rabbit & Jackson ImmunoResearch & $711-165-152$ \\
\hline AffiniPure Donkey Anti-Mouse & Jackson ImmunoResearch & 715-175-151 \\
\hline
\end{tabular}

Table 2. Reagents needed for the methods described in this chapter. 


\section{Reagent and equipment setup}

The setup for the reagents and equipment listed is as follows.

\begin{tabular}{|c|c|}
\hline Reagent & Setup \\
\hline ES medium & $\begin{array}{l}\text { For } 500 \mathrm{ml} \text { of ES medium, add the following components: } \\
400 \mathrm{ml} \mathrm{DMEM}, 75 \mathrm{ml} \mathrm{FBS}, 5 \mathrm{ml} \text { Pen/Strep, } 5 \mathrm{ml} \text { 2ME ( } 100 \\
\mathrm{mM}), 5 \mathrm{ml} \mathrm{L} \text {-glutamine, } 5 \mathrm{ml} \mathrm{NEAA}, 5 \mathrm{ml} \text { nucleosides, } 5 \mathrm{ml} \\
\text { 2ME, and } 50 \mu \mathrm{Ll} \text { LIF. }\end{array}$ \\
\hline EB medium & $\begin{array}{l}\text { For } 500 \mathrm{ml} \text { of EB medium, add the following components: } \\
450 \mathrm{ml} \mathrm{DMEM}, 25 \mathrm{ml} \mathrm{KSR}, 5 \mathrm{ml} \text { sodium pyruvate, } 5 \mathrm{ml} \\
\text { Pen/Strep, } 5 \mathrm{ml} 2 \mathrm{ME}(100 \mathrm{mM}), 5 \mathrm{ml} \text { L-glutamine, and } 5 \mathrm{ml} \\
\text { NEAA. }\end{array}$ \\
\hline DMEM/FBS medium & $\begin{array}{l}\text { For } 500 \mathrm{ml} \text { of feeder cells medium, add the following } \\
\text { components: } 440 \mathrm{ml} \text { DMEM, } 50 \mathrm{ml} \text { FBS, } 5 \mathrm{ml} \text { NEAA, and } 5 \\
\text { ml Pen/Strep. }\end{array}$ \\
\hline N2 medium & $\begin{array}{l}\text { For } 100 \mathrm{ml} \text { of } \mathrm{N} 2 \text { medium, add } 96 \mathrm{ml} \text { DMEM/F12, } 1 \mathrm{ml} \mathrm{N}-2 \text {, } \\
1 \mathrm{ml} \text { Pen/Strep, } 1 \mathrm{ml} \text { L-glutamine, } 1 \mathrm{ml} \text { NEAA, } 4 \mu \mathrm{l} \mathrm{FGF-2,} \\
\text { and } 100 \mu \mathrm{l} \text { laminin. }\end{array}$ \\
\hline B27/Neurobasal medium & 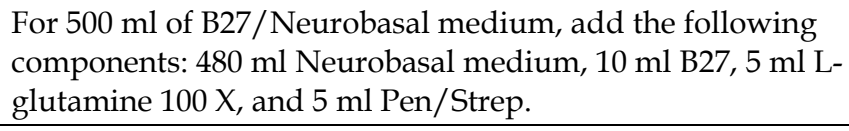 \\
\hline Gelatin $0.1 \%$ & $\begin{array}{l}\text { Dissolve } 100 \mathrm{mg} \text { of gelatin in } 90 \mathrm{ml} \text { warm }\left(\sim 60^{\circ} \mathrm{C}\right) \text { distilled } \\
\text { water. Sterilize by autoclaving and store at room } \\
\text { temperature. }\end{array}$ \\
\hline $\begin{array}{l}\text { 25x FGF stock solution } \\
\left(100 \mu \mathrm{g} \mathrm{ml}^{-1}\right)\end{array}$ & $\begin{array}{l}\text { Dissolve } 25 \mathrm{mg} \text { recombinant mouse FGF in } 250 \mathrm{ml} \text { of sterile } \\
\text { PBS. Store at } \sim 20^{\circ} \mathrm{C} \text {. }\end{array}$ \\
\hline 5x Poly-D-Lysine & $\begin{array}{l}\text { Dissolve } 50 \mathrm{mg} \text { poly-D-lysine in } 333.3 \mathrm{ml} \text { distilled water } \\
\text { and rinse the package with the water. Filter the solution } \\
\text { with a } 0.22-\mu \mathrm{m} \text { bottle top filter. Aliquot } 5 \mathrm{ml} \text { into } 15-\mathrm{ml} \\
\text { conical tubes and store at }-20^{\circ} \mathrm{C} \text {. }\end{array}$ \\
\hline $\begin{array}{l}\text { Hepes-buffered salt } \\
\text { solution (HBSS) }\end{array}$ & 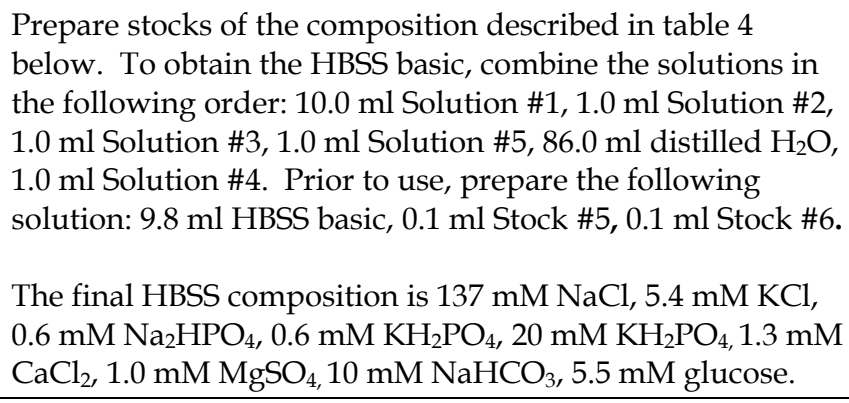 \\
\hline
\end{tabular}

Table 3. Setup of reagents needed for the methods described. 


\begin{tabular}{|c|c|}
\hline Stock & Preparation \\
\hline 1 & $\begin{array}{l}\text { In } 90 \mathrm{ml} \text { of distilled } \mathrm{H}_{2} \mathrm{O} \text {, dissolve } 8.0 \mathrm{~g} \mathrm{NaCl} .0 .4 \mathrm{~g} \mathrm{KCl} \text {, and fill to } 100 \mathrm{ml} \\
\text { with distilled } \mathrm{H}_{2} \mathrm{O} \text {. }\end{array}$ \\
\hline 2 & $\begin{array}{l}\text { In } 90 \mathrm{ml} \text { of distilled } \mathrm{H}_{2} \mathrm{O} \text {, dissolve } 0.41 \mathrm{~g} \mathrm{Na}_{2} \mathrm{HPO}_{4} \text { (anhydrous), } 0.80 \mathrm{~g} \\
\mathrm{KH}_{2} \mathrm{PO}_{4} \text {, and fill to } 100 \mathrm{ml} \text { with distilled } \mathrm{H}_{2} \mathrm{O}\end{array}$ \\
\hline 3 & Add $0.72 \mathrm{~g} \mathrm{CaCl}_{2}$ to $50 \mathrm{ml}$ of distilled $\mathrm{H}_{2} \mathrm{O}$ \\
\hline 4 & Add $1.23 \mathrm{~g} \mathrm{MgSO}_{4} \times 7 \mathrm{H}_{2} \mathrm{O}$ to $50 \mathrm{ml}$ of distilled $\mathrm{H}_{2} \mathrm{O}$ \\
\hline 5 & Add $4.76 \mathrm{~g}$ Hepes to $10 \mathrm{ml}$ of distilled $\mathrm{H}_{2} \mathrm{O}$ \\
\hline 6 & Add $0.9 \mathrm{~g}$ Glucose to $10 \mathrm{ml}$ of distilled $\mathrm{H}_{2} \mathrm{O}$ \\
\hline 7 & Add $0.84 \mathrm{~g} \mathrm{NaHCO}_{3}$ to $10 \mathrm{ml}$ of distilled $\mathrm{H}_{2} \mathrm{O}$ \\
\hline
\end{tabular}

Table 4. Preparation of the stock solutions needed to prepare HBSS. The combination of these stock solutions in described in table 3.

\begin{tabular}{|l|l|}
\hline Equipment & Setup \\
\hline Gelatin-coated plate & $\begin{array}{l}\text { Add } 5 \mathrm{ml} \text { of } 0.1 \% \text { (wt/vol) gelatin solution into a plate so that } \\
\text { it covers the entire bottom of the plate. Incubate the plate for } \\
\text { 20 min at room temperature. }\end{array}$ \\
\hline & $\begin{array}{l}\text { Autoclave cover slips. Place sterilized cover slips into the } \\
\text { wells of a 24-well plate. Dilute the } 5 \times \text { poly-D-lysine to } 1 \times \text { with } \\
\text { sterile distilled water plate except for the outermost wells. } \\
\text { Add 0.5-1 ml of the } 1 \times \text { poly-D-lysine solution to cover the } \\
\text { Poly-D-lysine (PDL) } \\
\text { cover slips } \\
\text { remove the PDL and wash the plates with sterile deionized } \\
\text { water and dry in a cell culture hood. }\end{array}$ \\
\hline
\end{tabular}

Table 5. Setup for the equipment needed for the methods described.

\section{Methods}

The generation of neurospheres and subsequent neuronal differentiation from ES cells is achieved through the stages described in the protocols below.

\subsection{Maintenance of ES cells}

Place R1 ES cells (Nagy et al., 1993) on $10 \mathrm{~cm}$ gelatin-coated dishes with $12 \mathrm{ml}$ of ES medium in a humidified chamber in a $5 \% \mathrm{CO}_{2} /$ air mixture at $37^{\circ} \mathrm{C}$. Change the medium every day. When the cells reach $80-90 \%$ confluence split them to two dishes as follows: wash the cells with $1 x$ PBS twice, then add $2 \mathrm{ml}$ of $1 x$ trypsin-EDTA. Rock the dish to ensure that the solution covers all the cells. Incubate the dish for $5 \mathrm{~min}$ at $37^{\circ} \mathrm{C}$. Pipette up and down to break up clumps and obtain a good dissociation of cells. Pipette $8 \mathrm{ml}$ ES medium to inhibit further tryptic activity and transfer to $15-\mathrm{ml}$ conical tubes. Spin at $1000 \mathrm{rpm}$ for $3 \mathrm{~min}$. Aspirate the medium from cells and resuspend the pellet in $6 \mathrm{ml}$ of fresh ES medium.

Transfer $3 \mathrm{ml}$ of cell suspension into a new $10 \mathrm{~cm}$ gelatin-coated dish containing $9 \mathrm{ml}$ of fresh ES medium.

\subsection{Generation of embryoid bodies}

Aspirate the medium, add $2 \mathrm{ml}$ of $1 \mathrm{x}$ trypsin-EDTA and incubate for $5 \mathrm{~min}$ at $37{ }^{\circ} \mathrm{C}$. Dissociate the cells by thoroughly pipetting several times with a P1000 Pipetman. Monitor 
the trypsinization under an inverted microscope. If the separation of the cells is not complete, continue the treatment with trypsin for additional 2-3 min.

Transfer the cell suspension into a 15-ml sterile conical tube. Pellet the cells centrifugation for $5 \mathrm{~min}$ at $1200 \mathrm{rpm}$; then resuspend the cell pellet in $10 \mathrm{ml}$ EB medium.

Count the cells with a cell counter and plate $5 \times 10^{5}$ ES cells per well in 6-well ultra low attachment plates in EB medium. Embryoid bodies should appear by overnight incubation.

Culture plates for 7 days. Change the medium every other day as follows: Collect the EBs in suspension from the plate and transfer into a $15 \mathrm{ml}$ conical tube. Leave the conical tube for 15 minutes to allow the EBs to settle to the bottom of the tube. Aspirate the medium and add $12 \mathrm{ml}$ of fresh EB medium. Transfer the EBs suspension into a new 6-well ultra low attachment plates.

\subsection{Neurosphere generation and neuronal differentiation}

Collect EBs and remove the medium as described in the previous step.

Count the number of EBs and prepare an EBs suspension in Feeder medium at a density of 40-50 EBs/ml.

Transfer 40-50 intact EBs to non-coated $10 \mathrm{~cm}$ cell culture dish containing $12 \mathrm{ml}$ DMEM/FBS medium.

Culture until cells reach confluence, changing medium every 2-3 days.

Aspirate the medium, add $2 \mathrm{ml}$ of trypsin-EDTA solution and incubate for $5 \mathrm{~min}$ at $37^{\circ} \mathrm{C}$. Dissociate cells thoroughly by pipetting with a P1000 Pipetman. Pipette $8 \mathrm{ml}$ Feeder medium and transfer the cell suspension to a 15-ml conical tube.

Centrifuge for $5 \mathrm{~min}$ at $1200 \mathrm{rpm}$. Aspirate the medium and resuspend the cells in $12 \mathrm{ml}$ DMEM/FBS. Culture the cells until confluence.

Trypsinize as described in section 4.2 and culture cells for other two passages.

Transfer the neurospheres floating in the culture medium into 50-ml conical tubes and allow them to settle for 10 minutes. Collect the supernatant containing neurospheres. Trypsinize cells attached to the bottom of the plate as described in section 6.2 and culture to generate new neurospheres.

\subsection{Neuronal differentiation}

Resuspend the neurospheres in the appropriate volume of N2 medium and culture for differentiation in a 24-well plate (15-20 neurospheres/well) containing poly-D-lysine-coated cover slips. Replace a half volume medium every other day.

At day 7 exchange N2 medium to B27/Neurobasal medium and let the cells differentiate for 10 more days with a medium change every other day.

\section{Characterization and functional analysis of neurons}

Selective immunocytochemistry can be performed according to standard procedures as described in the following sections.

\subsection{Cell cultures}

Plate the neurospheres on PDL-treated cover slips, and culture according to experimental protocols with the same conditions described above. 


\subsection{Immunocytochemistry procedure}

Fix mouse neurospheres-derived neurons for 20 minutes at room temperature in a $4 \%$ paraformaldehyde solution (prepared from stock 16\% Electron Microscopy Sciences, 15710-6 in 1X Premixed PBS Buffer at pH 7: Roche, 11666789001)

After three 10-minutes washes in PBS at room temperature, perform a blocking step for 1 hour in 10\% of Normal Donkey Serum (NDS, Jackson ImmunoResearch, 017-000-121) supplemented with 0.01\% TritonX-100 (Fluka, BP151-100).

Incubate the samples overnight with primary antibodies diluted in $10 \%$ of NDS in order to detect the expression of Tubulin III (R\&D Systems, MAB1195) and of the ubiquitous NMDA receptor subunit NR1. (Rabbit Anti-NMDAR1, Abcam ab68144; 1/250).

After three 10-minutes washes in PBS at room temperature, use fluorescently labeled secondary antibodies for detection (Cy3 AffiniPure Donkey Anti-Rabbit [Jackson ImmunoResearch, 711-165-152] or Cy5 AffiniPure Donkey Anti- Mouse [Jackson ImmunoResearch, 715-175-151]).

After three 10-minutes washes in PBS at room temperature, treat the cells with bisBenzimide $\mathrm{H}$ 33342 trihydrochloride (Sigma B-2261) for 2 minutes, to stain nuclei with 405nm fluorescence.

After two 10-minutes washes, in PBS remove the cover slip from the plates and mount on glass slide with mounting solution (Gelvatol).

Images can be acquired using a laser scanning confocal microscope (FluoView 1000, Olympus). The microscope is equipped with spectral detector technology that provides precise wavelength separation of the emitted light.

\subsection{Intracellular $\mathrm{Ca}^{2+}$ measurement}

For intracellular $\mathrm{Ca}^{2+}$ concentration $\left(\left[\mathrm{Ca}^{2+}\right]_{\mathrm{i}}\right)$ measurements, incubate cells for $45 \mathrm{~min}$ at $37^{\circ} \mathrm{C}$ with $5 \mu \mathrm{M}$ fura-2-AM (cell permeant; Invitrogen, F-1221) and $5 \mu \mathrm{g} / \mathrm{ml}$ bovine serum albumin (Sigma A-6003) in Hepes-buffered salt solution (standard HBSS).

Then, wash cells 3 times for 5 min each with standard HBSS and place the cover slips onto a perfusion chamber on a DM IRM inverted microscope (Leica) fitted with a Leica HC N PLAN BD 50X oil immersion objective. $\left[\mathrm{Ca}^{+}\right]_{\mathrm{i}}$ can be monitored in single cells using excitation light provided by a $75 \mathrm{~W}$ xenon lamp-based monochromator (Ushio, Japan). Emitted light can be detected using a CCD camera (Orca; Hamamatsu, Shizouka, Japan). Alternatively, illuminate cells with 340 and $380 \mathrm{~nm}$ light for fura-2. Emitted fluorescence can be passed through a 500 nm longpass dichromatic mirror and a $535 \pm 40 \mathrm{~nm}$ bandpass filter (Omega Optical).

Analyze acquired data using software such as Simple PCI (Compix, Inc., Cranberry, PA) as the 340/380 ratio. Measure fluorescence in 15-25 individual neurons for each cover slip. Subtract background fluorescence, determined from three or four cell-free regions of the cover slips, from all signals prior to calculating the ratios. Choose the excitation light exposure time and a neutral density filter to avoid saturation of the fluorescence signal.

\section{Conclusion}

Neural induction from pluripotent stem cells often yield heterogeneous cell populations that can hamper quantitative and comparative analyses. There is a need for improved differentiation and enrichment procedures that generate highly pure populations of neural stem cells (NSC), glia and neurons. The method described here allows an efficient generation of neurospheres from mES cells. On day-in vitro 16 after neural induction about $50 \%$ of the cells derived from neurospheres show a neural morphology, a significant 
expression of neuronal markers such as Tuj1 and the ubiquitous NMDA receptor subunit NR1 (figure 2), and a functional NMDAR-dependent calcium influx mediated by exogenous glutamate administration (figure 3).
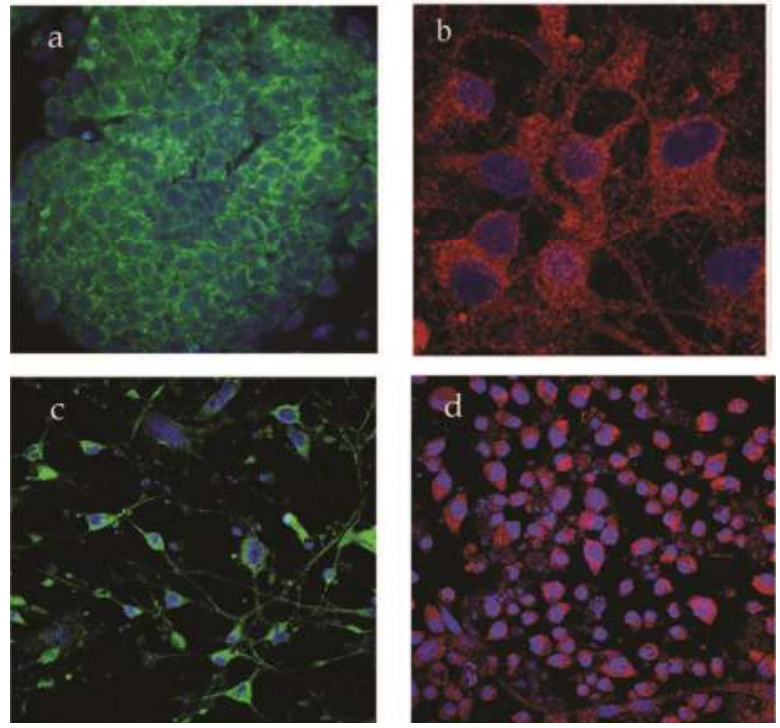

Fig. 2. Neurosphere differentiation. a) Immunostaining of a neurospheres with antibody specific to NMDA receptor (NR1 sub-unit, green). b-c) Staining of neurosphere-derived neurons with (b) NMDA receptor (NR1 sub-unit, red) and (c) $\beta$-tubulin III (green). d) staining of astrocytes differentiated from neurospheres with GFAP (red). Nuclei were counterstained with DAPI (blue). [Images taken by authors.]
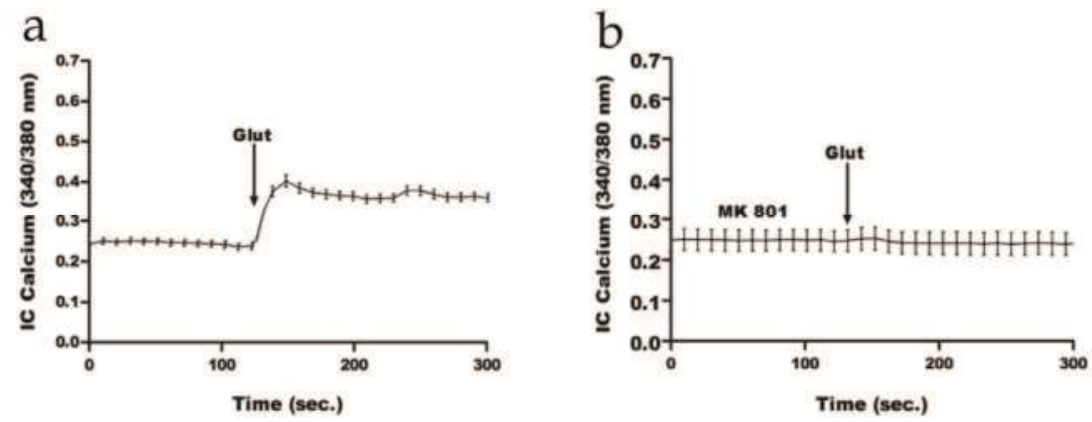

Fig. 3. Analysis of calcium influx in neurons differentiated from neurospheres indicated by glutamate. a) Administration of $10 \mu \mathrm{M}$ glutamate (glu) in neurons causes an increase in $\left[\mathrm{Ca}^{2+}\right]_{\mathrm{i}}(340 / 380=0.32 \pm 0.05 \mathrm{a})$. b) Glu-induced increase in $\left[\mathrm{Ca}^{2+}\right]_{\mathrm{i}}$ in $\mathrm{R} 1$ cells is blocked by treatment with MK801, an NMDAR-specific antagonist, suggesting that NMDARs are the predominant glutamate-sensitive receptors in neurospheres-derived neurons. [Data generated by authors.] 
Furthermore, the rest of the cellular population show typical astroglial morphology. This chapter illustrates the utility mouse ES cells as a simple system able to develop populations of viable NSC and neurons. The method described here will enable downstream studies that require consistent and defined cell populations to study and characterize the physiopathology of the neuronal differentiation.

This procedure allows generation of a cell line derived from mouse ES cells which continually produces neuropheres in the absence of FGF-2 and EGF and coculturing. By generating neurospheres via this method, one can use them for a variety of purposes for further experiments with neurons.

\section{References}

Campos LS., Leone DP., Relvas JB., Brakebusch C., Fassler R., Suter U., et al. (2004). Beta1 integrins activate a MAPK signalling pathway in neural stem cells that contributes to their maintenance. Development, Vol. 131, No. 14 (July 2004), pp. 3433-3444. ISSN 1011-6370.

Conti L., Pollard SM., Gorba T., Reitano E., Toselli M., Biella G., Sun Y., Sanzone S., Ying QL., Cattaneo E. \& Smith A. (2005). Niche-independent symmetrical self-renewal of a mammalian tissue stem cell. PLoS Biol, Vol. 3, No. 9 (Sep 2005)pp. e283. ISSN 1545-7885.

Gaspard N. \& Vanderhaeghen P. (2011) From stem cells to neural networks: recent advances and perspectives for neurodevelopmental disorders. Dev Med Child Neurol, Vol. 53, No. 1 (Jan 2011), pp. 13-7. ISSN 0012-1622.

Kawasaki H., Mizuseki K., Nishikawa S., Kaneko S., Kuwana Y., Nakanishi S., Nishikawa SI. \& Sasai Y. (2000). Induction of midbrain dopaminergic neurons from ES cells by stromal cell-derived inducing activity. Neuron, Vol. 28, No. 1 (Oct 2000), pp. 31-40. ISSN 0986-6273.

Moors M., Rockel TD., Abel J., Cline JE., Gassmann K., Schreiber T., Schuwald J., Weinmann N. \& Fritsche E. (2009). Human neurospheres as three-dimensional cellular systems for developmental neurotoxicity testing. Environmental Health Perspectectives, Vol. 117, No. 7 (July 2009), pp. 1131-8. ISSN 0091-6765.

Morizane A., Takahashi J., Shinoyama M., Ideguchi M., Takagi Y., Fukuda H., Koyanagi M., Sasai Y. \& Hashimoto N. (2006). Generation of graftable dopaminergic neuron progenitors from mouse ES cells by a combination of coculture and neurosphere methods. J Neurosci Res, Vol. 83, No. 6 (May 2006), pp. 1015-27. ISSN 0306-4522.

Nagy A., Rossant J., Nagy R., Abramow-Newerly W. \& Roder JC. (1993). Derivation of completely cell culture-derived mice from early-passage embryonic stem cells. Proc Natl Acad Sci USA, Vol. 90, No. 18, (Sep 1993), pp. 8424-8428. ISSN 0027-8424

Reynolds BA \& Weiss S. (1992). Generation of neurons and astrocytes from isolated cells of the adult mammalian central nervous system. Science, Vol. 255, No. 5052 (Mar 1992), pp. 1707-10. ISSN 0193-4511

Taupin P. \& Gage FH. (2002). Adult neurogenesis and neural stem cells of the central nervous system in mammals. J Neurosci Res, Vol. 89, No. 6 (Sep 2002), pp. 745-9. ISSN 0360-4012.

Temple S. (1989). Division and differentiation of isolated CNS blast cells in microculture. Nature, Vol. 340, No. 6233 (Aug 1989), pp. 471-3. ISSN 0028-0836.

Yoshimura S., Takagi Y., Harada J., Teramoto T., Thomas SS., Waeber C., Bakowska JC., Breakefield XO. \& Moskowitz MA. (2001). FGF-2 regulation of neurogenesis in adult hippocampus after brain injury. Proc Natl Acad Sci U S A, Vol. 98, No. 10, (May 2001), pp. 5874-9. ISSN 0027-8424. 


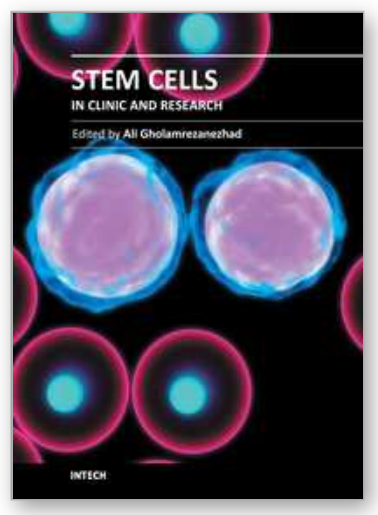

\author{
Stem Cells in Clinic and Research \\ Edited by Dr. Ali Gholamrezanezhad
}

ISBN 978-953-307-797-0

Hard cover, 804 pages

Publisher InTech

Published online 23, August, 2011

Published in print edition August, 2011

Based on our current understanding of cell biology and strong supporting evidence from previous experiences, different types of human stem cell populations are capable of undergoing differentiation or trans-differentiation into functionally and biologically active cells for use in therapeutic purposes. So far, progress regarding the use of both in vitro and in vivo regenerative medicine models already offers hope for the application of different types of stem cells as a powerful new therapeutic option to treat different diseases that were previously considered to be untreatable. Remarkable achievements in cell biology resulting in the isolation and characterization of various stem cells and progenitor cells has increased the expectation for the development of a new approach to the treatment of genetic and developmental human diseases. Due to the fact that currently stem cells and umbilical cord banks are so strictly defined and available, it seems that this mission is investigationally more practical than in the past. On the other hand, studies performed on stem cells, targeting their conversion into functionally mature tissue, are not necessarily seeking to result in the clinical application of the differentiated cells; In fact, still one of the important goals of these studies is to get acquainted with the natural process of development of mature cells from their immature progenitors during the embryonic period onwards, which can produce valuable results as knowledge of the developmental processes during embryogenesis. For example, the cellular and molecular mechanisms leading to mature and adult cells developmental abnormalities are relatively unknown. This lack of understanding stems from the lack of a good model system to study cell development and differentiation. Hence, the knowledge reached through these studies can prove to be a breakthrough in preventing developmental disorders. Meanwhile, many researchers conduct these studies to understand the molecular and cellular basis of cancer development. The fact that cancer is one of the leading causes of death throughout the world, highlights the importance of these researches in the fields of biology and medicine.

\title{
How to reference
}

In order to correctly reference this scholarly work, feel free to copy and paste the following:

Roberto Di Maio, Kommu Naga Mohan, Brianna Heath and Leonardo D'Aiuto (2011). Spontaneous Generation of Neurospheres from Mouse Embryonic Stem Cells, Stem Cells in Clinic and Research, Dr. Ali Gholamrezanezhad (Ed.), ISBN: 978-953-307-797-0, InTech, Available from:

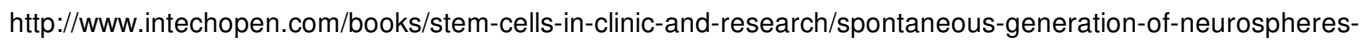
from-mouse-embryonic-stem-cells

\section{INTECH}

open science | open minds 


\section{InTech Europe}

University Campus STeP Ri

Slavka Krautzeka 83/A

51000 Rijeka, Croatia

Phone: +385 (51) 770447

Fax: +385 (51) 686166

www.intechopen.com

\section{InTech China}

Unit 405, Office Block, Hotel Equatorial Shanghai No.65, Yan An Road (West), Shanghai, 200040, China 中国上海市延安西路65号上海国际贵都大饭店办公楼 405 单元 Phone: +86-21-62489820

Fax: +86-21-62489821 
(C) 2011 The Author(s). Licensee IntechOpen. This chapter is distributed under the terms of the Creative Commons Attribution-NonCommercialShareAlike-3.0 License, which permits use, distribution and reproduction for non-commercial purposes, provided the original is properly cited and derivative works building on this content are distributed under the same license. 